\title{
Midgut Nonrotation in an Adult Patient and Ladd's Procedure
}

\section{Yetişkin Hastada Midgut Nonrotasyonu ve Ladd Prosedürü}

\author{
(1) Huriye Hande Aydınlı1, () Özgen Işık2, (1) Tuncay Yılmazlar2 \\ ${ }^{1}$ New York University, School of Medicine, Department of Surgery, Division of General Surgery, New York, United States \\ 2Uludağ University Faculty of Medicine, Department of Surgery, Bursa, Turkey
}

\section{HIIIIII ABSTRACT}

Midgut malrotation is a congenital anomaly that usually occurs during infancy. The most common type is the "classic" form, which is defined as complete failure of rotation of both proximal (duodenojejunal limb) and distal (cecocolic) small bowel loops (nonrotation). Delayed diagnosis of midgut malrotation anomalies may lead to progression to catastrophic complications including volvulus and ischemic necrosis. Ladd's procedure is the standard of care. We aimed to report a brief case of a midgut nonrotation in an adult male patient.

Keywords: Midgut, malrotation, anomaly

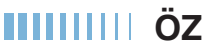

Midgut malrotasyonu çoğunlukla doğum sonrası erken dönemde görülen konjenital bir anomalidir. En sık tipi hem proksimal (duodenojejunal bacak) hem de distal (çekokolik) ince barsak anslarının rotasyonunun olmaması ile karakterize olan klasik tiptir. Midgut malrotasyon anomalilerinde gecikmiş tanı volvulus ve iskemik nekrozu da içerebilen katastrofik komplikasyonlara yol açabilir. Ladd prosedürü standart tedavi şeklidir. Burada yetişkin bir erkek hastada midgut nonrotasyon olgusunu bildirmeyi amaçladık.

Anahtar Kelimeler: Midgut, malrotasyon, anomaly

\section{Introduction}

Midgut malrotation is a congenital anomaly and usually occurs in infancy. The most common type is the "classic" form of malrotation defined as complete failure of rotation of both proximal (duodenojejunal limb) and distal (cecocolic) small bowel loops (nonrotation). ${ }^{1}$ Although this pathology may be a common diagnosis for pediatric surgeons, this may not be the case for surgeons treating adults in general. Delayed diagnosis of midgut malrotation anomalies can cause progression to catastrophic complications including volvulus and ischemic necrosis. We aimed to report a case of midgut nonrotation in an adult male patient and to increase familiarity with this disease among surgeons treating adults.

\section{Case Report}

A 29 year-old male patient was referred to our clinic from an outside hospital with a suspected inflammatory bowel disease due to ongoing abdominal pain, nausea, vomiting and constipation for the last 5 days. He was otherwise healthy with a past medical history significant only for benign prostatic hypertrophy and no prior abdominal surgeries. He was admitted to our clinic with an initial diagnosis of intestinal obstruction.

On physical examination, he was afebrile and hemodynamically stable with no signs of acute abdomen. Computerized tomography scan of the abdomen showed findings consistent with proximal small bowel obstruction. His initial management consisted of intravenous (IV)

Presented in: This study was presented as a poster at the XVI. Turkish National Colon and Rectal Surgery Congress in Antalya, Turkey in May 15-20, 2017.

Address for Correspondence/Yazışma Adresi: Özgen Işık MD,

Uludă University Faculty of Medicine, Department of Surgery, Bursa, Turkey

Phone: +90 5358952305 E-mail: ozgen006@yahoo.com ORCID ID: orcid.org/ 0000-0002-9541-5035

Received/Geliş Tarihi: 30.12.2018 Accepted/Kabul Tarihi: 12.01.2019 


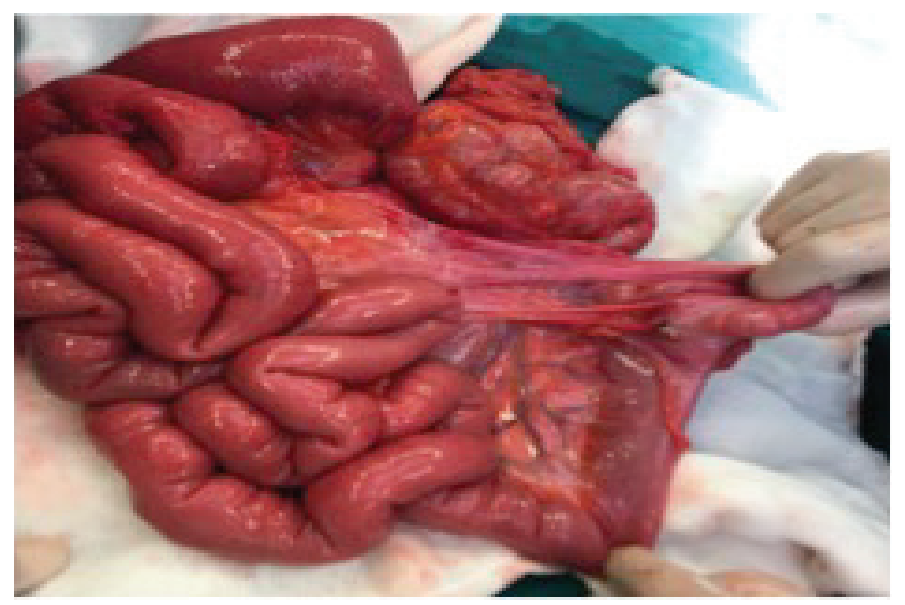

Figure 1. Intraoperative view of small bowel and colon (after excision of Ladd bands and appendectomy)

fluids, IV antibiotics and nasogastric decompression. Over a 24-hour period, the nasogastric tube output was 2 liters and clinical findings of mechanical obstruction did not improve. He consented for an exploratory laparotomy in the emergency settings. Intraoperatively, small bowel was found to be segregated into the right abdomen, consistent with midgut nonrotation anomaly. Subsequently, following steps were performed: counterclockwise detorsion of the small bowel, internal hernia reduction and take down of Ladd's band in the right upper quadrant (RUQ). Following these steps, cecum and appendix were identified in the left lower quadrant, and an appendectomy was also performed. Relocation of the duodenum to the RUQ was undertaken and subsequent to that colon was placed in the left abdomen. The affected small bowel segment was re-examined in terms of perfusion, and resection was deemed not necessary per operating surgeon (Figure 1). The patient's abdomen was closed primarily and he was transferred to the surgical floor. Postoperative course was uneventful and patient was discharged home on postoperative day 7 .

\section{Discussion}

Intestinal malrotation occurs due to the lack of normal rotation and fixation of the embryologic gut during the first trimester of gestation. ${ }^{2}$ Most of the patients with intestinal malrotation present during infancy with acute clinical presentation of intestinal obstruction. Although rare, adult patients more commonly present with chronic symptoms including intermittent vomiting, abdominal pain, weight loss, and food intolerance that lasts for more than 6 months. ${ }^{3}$ High index of suspicion is required to make an early diagnosis and intervention and subsequently to prevent progression to bowel necrosis with midgut volvulus in adult cohort. Imaging studies are usually suggestive of the disease, but in most cases it is diagnosed intraoperatively. An upper gastrointestinal series can be used to establish the diagnosis preoperatively; nevertheless surgery shouldn't be postponed in patients with acute clinical presentation for further imaging. The choice of treatment depends on the severity of the presentation. Ladd's procedure is the standard of care and it can be scheduled electively in patients with chronic disease or as an emergency in the acute setting. ${ }^{2}$ Nasogastric decompression, volume resuscitation and antibiotics are important aspects of preoperative preparation. Ladd's procedure is divided into the following 5 steps: initially, the mesentery should be assessed for any twists and signs of ischemia, and counterclockwise detorsion of volvulus is achieved if applicable. Following this, Ladd bands, which are fibrous bands between cecum and duodenum that can cause duodenal obstruction, should be divided. In addition, intermesenteric fibrous bands between bowel loops should be identified by running the entire bowel and should be divided. Due to higher incidence of aberrant location of the appendix, appendicitis in patients with malrotation was found to have a higher complication rate. An appendectomy is routinely performed as a part of the Ladd's procedure. The final step consists of placing the bowel in the corrected anatomic position as small bowel in the right abdomen, colon in the left abdomen, and cecum in the left upper quadrant. ${ }^{2}$ Postoperative morbidity and reoperation rates are high in adult patients when compared to pediatric cohort. This might be due to longer time to diagnosis and more advanced disease. ${ }^{4}$

We shared an acute adult presentation of an intestinal malrotation with midgut volvulus. Surgeons primarily serving adult patient cohorts should keep malrotation as a differential diagnosis. Intestinal malrotation should be suspected in patients with abdominal pain with or without accompanying bowel obstruction symptoms. In addition, a more subtle presentation with chronic nonspecific gastrointestinal symptoms may be related to intestinal malrotation.

\section{Ethics}

Informed Consent: Written informed consent obtained

Peer-review: Externally peer-reviewed.

\section{Authorship Contributions}

Surgical and Medical Practices: Ö.I., T.Y., Concept: Ö.I., T.Y., Design: Ö.I., T.Y., Data Collection or Processing: Ö.I., T.Y., Analysis or Interpretation: Ö.I., H.H.A., Literature Search: Ö.I., H.H.A., Writing: Ö.I., H.H.A.

Conflict of Interest: No conflict of interest was declared by the authors.

Financial Disclosure: The authors declared that this study received no financial support. 


\section{References}

1. Dietz DW, Walsh RM, Grundfest-Broniatowski S, Lavery IC, Fazio VW, Vogt DP. Intestinal malrotation: a rare but important cause of bowel obstruction in adults. Dis Colon Rectum 2002;45:1381-1386.

2. Buchmiller T. Intestinal malrotation in adults 2017 [Available from: https://www-uptodate-com.ezproxy.med.nyu.edu/contents/intestinal- malrotation-in-adults?search=intestinal\%20malrotation\&source=search_ result \&selected Title $=2 \sim 41 \&$ usage_type $=$ default $\&$ display_ rank=2\#H10198704

3. Yanez R, Spitz L. Intestinal malrotation presenting outside the neonatal period. Arch Dis Child 1986;61:682-685.

4. Durkin ET, Lund DP, Shaaban AF, et al. Age-related differences in diagnosis and morbidity of intestinal malrotation. J Am Coll Surg 2008;206:658-663. 